\title{
A Botanical Survey IN Grand Teton National Park: Plants USEd by NATIVE AMERICANS
}

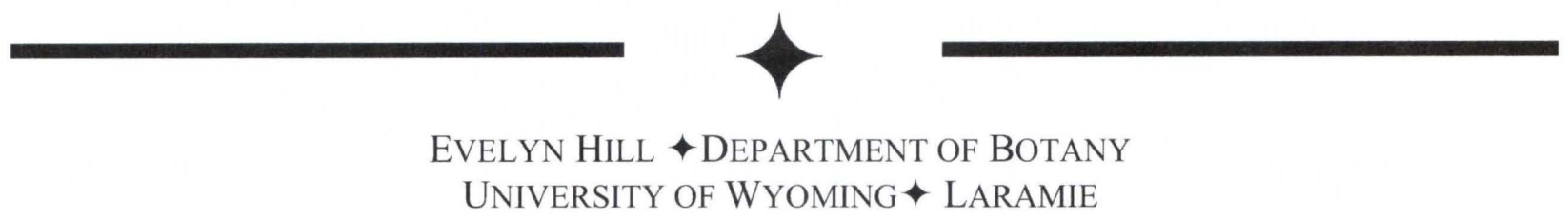

\section{$\downarrow \quad$ INTRODUCTION}

For the first time, in Grand Teton National Park (GTNP) an ethnobotanical plant collection, archaeological and historic site reports, and the literature of early plant usage have been integrated into one document.

\section{$\downarrow \quad$ RESULTS}

\begin{tabular}{|l|}
\hline $\begin{array}{l}\text { Twenty-two plant families from two periods } \\
\text { in GTNP: Prehistoric and 2004-2005 }\end{array}$ \\
\hline Adoxaceae \\
\hline Alismataceae \\
\hline Apiaceae \\
\hline Asteraceae \\
\hline Betulaceae \\
\hline Brassicaceae \\
\hline Caprifoliaceae \\
\hline Cornaceae \\
\hline Cupressaceac \\
\hline Cyperaceae \\
\hline Ericaceae \\
\hline Fabaceae \\
\hline Lamiaceae \\
\hline Liliaceae \\
\hline Pinaceae \\
\hline Poaceae \\
\hline Polygonaceae \\
\hline Ranunculaceae \\
\hline Rosaceae \\
\hline Salicaceae \\
\hline Typhaceae \\
\hline Urticaceae \\
\hline
\end{tabular}

Table 1. 22 plant families from two periods in GTNP, found in both 2004-2005 collections (Appendix $\mathrm{C}^{*}$ ), and in excavations from 23 hearths (Appendix A*).
The total botanical collections yielded 49 families, with 119 species (Appendix $\mathrm{A}^{*}$ ). The literature search produced a count of 328 ethnobotanically important taxa for GTNP. This count of 328 was reduced to 281 taxa, and of these 149 collections were made. Twenty-three species were collected more than once, one of these in the Scrophulariaceae, Castelleja miniata, is a hybrid cross with C. sulphurea, a first time collection, per B. Ernie Nelson of the Rocky Mountain Herbarium. One hundred seventy-nine taxa on the list were not encountered or, have no collection history in GTNP.

\begin{tabular}{|l|}
\hline $\mathbf{3 4}$ Archaeological Plant Families from 23 \\
Excavated sites in GTNP \\
\hline Family \\
\hline Adoxaceac \\
\hline Alismataceae \\
\hline Apiaceae \\
\hline Asteraceae \\
\hline Betulaceae \\
\hline Boraginaceae \\
\hline Brassicaceae \\
\hline Caprifoliaceae \\
\hline Chenopodiaceae \\
\hline Cornaceae \\
\hline Cupressaceae \\
\hline Cyperaceae \\
\hline Ephedraceae \\
\hline Ericaceae \\
\hline Fabiaceae \\
\hline Fagaceae \\
\hline Juncaceae \\
\hline Lamiaceae \\
\hline Liliaceae \\
\hline Malvaceae \\
\hline \\
\hline
\end{tabular}

* Appendix is available upon request. Contact UW-NPS through our website www.uwyo.edu/uwnps 


\begin{tabular}{|l|}
\hline Papaveraceae \\
\hline Pinaceac \\
\hline Poaceae \\
\hline Polygonaceae \\
\hline Potomogetonaceae \\
\hline Ranunculaceae \\
\hline Rosaceae \\
\hline Ruppiaceac \\
\hline Salicaceac \\
\hline Solanaceae \\
\hline Typhaceac \\
\hline Urticaceae \\
\hline Violaceae \\
\hline Zannichelliaceac \\
\hline
\end{tabular}

Table 2. Thirty-four plant families from 23 excavated archaeological sites in GTNP. These 34 families have 22 families identical with the 2004-2005 collections, and thus have a commonality of $65 \%$. Archaeological data is in Appendix A*.

The archaeological data generated a synthesis of 319 genera in 34 families. These are included in Appendix $\mathrm{A}^{*}$. Cultural continuity is exhibited by the comparisons of the archaeological and 2004-2005 collections in Table 2. The listing of so many of these taxa in the ethnobotanical literature, as traditionally useful plants, agrees with the evidence of plant use between 10,000 years BP and up until 100 years ago. The archaeological reports were also mostly unusable as a collection resource, having only three genera with species identified. These archaeological sources have been included as evidence of Native American plant use in this region.

Twenty-two families are common to both the archaeological sites and in the 2004-2005 GTNP collection (Table 3$)$. This represents 45\% (22/49= .448 ) in common with the archaeological plant analysis and $65 \%(22 / 34=.647)$ in common with the 2004-2005 plant collection (Table 2).

The plant uses by tribe, and if available, the part of the plant used with its preparation, are listed in Appendix $\mathrm{C}^{*}$. The information on usage is incomplete for many plants, the Native American tribal elders with this knowledge may not have passed it to younger individuals, and it became lost before it could be written down. Included in Appendix $\mathrm{C} *$ are plants searched for but not located or collected. Appendix $\mathrm{D}^{*}$ contains a vocabulary from Appendix $\mathrm{C}^{*}$; some of it is antiquated terminology by nature of the time and resource, but it is included for those employing plants for the indicated use per the literature.

\begin{tabular}{|c|c|}
\hline \multicolumn{2}{|c|}{$\begin{array}{c}\text { GTNP Plant Collection 2004-2005 } \\
48 \text { Families: } 118 \text { Species } \\
1 \text { Fungal Order: } 1 \text { species }\end{array}$} \\
\hline Family & Species \\
\hline Aceraceae & 1 \\
\hline Adoxaceae & 1 \\
\hline Alismataceae & 1 \\
\hline Alliaceae & 1 \\
\hline Apiaceac & 8 \\
\hline Asteraceac & 14 \\
\hline Berberidaceae & 1 \\
\hline Betulaceae & 2 \\
\hline Brassicaceae & 1 \\
\hline Calochortaceae & 1 \\
\hline Campanulaceae & 1 \\
\hline Caprifoliaceae & 2 \\
\hline Caryophyllaceae & 1 \\
\hline Celastraceae & 1 \\
\hline Convallariaceae & 1 \\
\hline Cornaceae & 1 \\
\hline Crassulaceae & 1 \\
\hline Cupressaceae & 1 \\
\hline Cyperaceae & 1 \\
\hline Elaeagnaceae & 1 \\
\hline Equisetaceae & 2 \\
\hline Ericaceae & 5 \\
\hline Fabaceae & 3 \\
\hline Gentianaceae & 2 \\
\hline Geraniaceae & 1 \\
\hline Grossulariaceae & 4 \\
\hline Hyacinthaceae & 1 \\
\hline Hydrophyllaceae & 1 \\
\hline Lamiaceae & 2 \\
\hline Linaceae & 1 \\
\hline Melanthiaceae & 4 \\
\hline Nymphaeaceae & 1 \\
\hline Onagraceae & 1 \\
\hline Pinaceae & 4 \\
\hline Poaceae & 2 \\
\hline Polemoniaceac & 2 \\
\hline Polygonaceae & 3 \\
\hline Portulacaceae & 1 \\
\hline Primulaceae & 1 \\
\hline Ranunculaceae & 8 \\
\hline Rhammaceae & 1 \\
\hline Rosaceae & 12 \\
\hline Salicaceae & 3 \\
\hline Saxifragaceae & 1 \\
\hline Scrophulariaceae & 6 \\
\hline Typhaceae & 2 \\
\hline Urticaceae & 1 \\
\hline Valerianaceae & 1 \\
\hline Lycoperdales, $\mathrm{Ca}$ & 1 \\
\hline
\end{tabular}

Table 3. Plant collection from the 2004-2005 field seasons in GTNP. 48 Families: 118 Species, and 1 Fungal Order: 1 Species (Appendix B*). Twenty-two of these 49 families are identical with the $\mathbf{2 2}$ families (Table 6) from the 2004205 collections, and thus have a commonality of $45 \%$.

\section{$\downarrow$ DISCUSSION}

The total possible taxa of ethnobotanically identifiable plants from literature searches and hearth

* Appendix is available upon request. Contact UW-NPS through our website www.uwyo.edu/uwnps 
reports for this study began with 328 taxa. Fifteen percent of this original plant collection list was excluded from my collecting efforts, reducing species sought to 281. The following four classifications address these exclusions.

1. Genus with no species specified. When more than one species occurs in a genus these were excluded.

2. Misidentification of genus and/or species by untrained individuals.

3. Incomplete synonymic trail of antiquated names to modern binomials.

4. Two taxa have no record of modern collection in GTNP (Dorn 2001). These are archaeological pollen, Quercus, and Ephedra (Larson 1995).

The assumption is that these species were well within the annual migration and trade range of Shoshone hunter-gatherers (Shimkin 1947). Edibles, medicinals, ceremonials, or utilitarian plants could have been transported into GTNP, prepared in a roasting pit, and consumed at that time, leaving only pollen as evidence (Adams 2006).

A compiled list of plants and their uses came from earlier travelers, ethnographers, explorers and the photographer Edward Curtis in the 1800s. Early botanists or those with some formal botanical training provided out-dated binomials or colloquial common plant names. These archaic names have changed through the years; most of them have a lineage to follow into currently usable Linnaean nomenclature.

Archaeological data from twenty-three sites, involving testing by shovel, auger, or major excavation, were unusable as a collection resource, because only three genera had specific species identified. These archeological sources have been included as evidence of early Native American use of plants in GTNP. These are included in Appendix B*.

Considerations of why there are not more than twenty-two taxa in common between the prehistoric and the 2004-2005 collections may include reasons of seasonal gathering practices, the availability of plants to collect when people were present, seed bearing species dependency on annually fluctuating moisture levels, and the possibility of taxa becoming locally extinct through global change. Prehistoric hearths may not have been discovered due to the water levels of Jackson Lake being too high, or fire and regrowth of vegetation covering the sites, or hearths simply not being inventoried. The age of archaeological sites 48TE509 and 48TE1039 indicate occupation during the Altithermal period in ethnobotanical history
Ethnobotanical plants in and around GTNP are listed in Appendix $C^{*}$. All of these plants were recorded as being used by, or present with the tribes, as referenced by their authors. Some plants may have been transported into GTNP (Shimkin 1947, Adams 2006, Reher 2004, Waldman 2000), as Quercus and Ephedra do not have a recorded history of growing in GTNP. Quercus is located in Carbon, Crook, and Campbell Counties in the State of Wyoming, Gallatin County in Montana and Uintah, Duchesne, Wasatch, Salt Lake, Davis, Weber and Cache Counties in Utah (USDA Plants Database). Ephedra has never been collected in the State of Wyoming Dorn (2001), but is reported to grow in Sweetwater County, Wyoming (USDA, Plants Database). These two plant taxa are from the Henn Site, (Larson 1995). Including those plants not found in GTNP, but reported in the literature as hearth contents, is important to illustrate the migration of peoples, the possibility of trade patterns, their understanding of plants, and their ways of living.

Botanical and ethnographic literature was compiled first, then, the addition of macrofloral and microfloral data gleaned from archaeological site reports and finally a plant collection from GTNP was included. By recognizing the traditional ways of plant use from the archaeological and literary records and using these same grounds for collecting, an old connection between culture and conservation is honored. Tribes of people returned yearly for plants and did not cause their extinction. Modern man needs to learn this lesson in so many areas of his life.

\section{$\downarrow$ Literature Cited}

Adams, R. 2003-2006. Personal communication.

Clarke, L. 1986. Jackson Lake Archaeological Project. Jackson, Wyoming.

Connor, M., B. Kolb, J. Behn, J. Groethe, C. A. Winchell, E. C. Svec. 1986. Midwest Archeological Center, Lincoln, Nebraska.

Cummings, L.S. 1987. Pollen and Macrofloral Analysis at Grand Teton National Park, 1986 Field Season. Manuscript on file, National Park Service, Midwest Archeological Center, Lincoln, Nebraska.

Cummings, L.S.. 1988. Pollen and Macrofloral Analyses of Four Sites around Jackson Lake, 
Wyoming. 1987 Field Season

Curtis, E S. 1911. The North American Indian. Johnson Reprint Corporation, New York. Toppan Rare Books Library, University of Wyoming, Laramie, Wyoming.

Dorn, R.D. 2001. Vascular Plants of Wyoming. Mountain West Publishing, Cheyenne.

Erichsen-Brown C. 1979. Medicinal and Other Uses of North American Plants, A Historical Survey with Special Reference to the Eastern Indian Tribes. DoverPublications, INC., New York.

Francis, J.E. 2002. Ancient Visions: Petroglyphs and Pictographs from the Wind River and Bighorn Country, Wyoming and Montana. University of Utah Press, Salt Lake.

Groethe, J., B. Kolb. 1985. Jackson Lake Survey. Midwest Archeological Center, Lincoln, Nebraska.

Guernsey, K.M. 2003-2006. Pers com. In E. Hill [ed.], Conversations in ethnobotany, private library access, Laramie.

Hart, J. 1996. Montana Native Plants and Early Peoples. Montana Historical Society Press, Helena.

Kindscher, K. 1992. Medicinal Wild Plants of the Prairies: An Ethnobotanical Guide. University of Kansas Press, Lawrence.

Larson, M.L. 1995. The Henn Site: Early Archaic to Protohistoric Occupation at the Jackson National Fish Hatchery. Prepared for the U. S. Fish and Wildlife Service, Denver, Colorado. Technical Report No. 7, Department of Anthropology, University of Wyoming, Laramie, Wyoming.

Lipp, F.J. 1996. Herbalism. Little, Brown and Company, Boston.

Love, C.M. 1972. An Archaeological Survey of the Jackson Hole Region, Wyoming. Unpublished M. A. Thesis, Department of Anthropology, University of Wyoming.

Martin, C. 2000. Herbal Remedies from the Wild. The Countryman Press, Woodstock.
Matz, S. 1987. Jackson Lake Archaeological Project. Jackson, Wyoming.

Matz, S. 1988. Jackson Lake Archaeological Project. Jackson, Wyoming.

Moerman, D. E. 1998. Native American Ethnobotany. Timber Press, Inc, Portland.

Moore, M. 1996. Medicinal Plants of the Mountain West. Museum of New Mexico Press, Santa Fe.

Reher, C.A. 2004. Pers com. In E. Hill [ed.], Personal conversations, and private library access. University of Wyoming, Department of Anthropology, Laramie, Wyoming.

Scott, L.J. 1987. Pollen and Macrofloral Analyses of Four Sites Around Jackson Lake, Wyoming.

Shimkin, D.B. 1947. Wind River Shoshone Ethnogeography. University of California Press, Berkeley.

Tilford, G. L. 1997. Edible and Medicinal Plants of the West. Mountain Press Publishing Company, Missoula.

U.S. Department of Agriculture. 2006. Natural Resource Conservation Service, Plants Database. http://plants.usda.gov/index.html.

University of Wyoming-National Park Service Research Station. 2004-2005. Dr. Henry Harlow, Director, UW-NPS Herbarium, Moran, Wyoming.

Vogel, V.J. 1973. American Indian Medicine. University of Oklahoma Press and Ballantine Books, New York.

Waldman, C. 2000. Atlas of the North American Indian. Checkmark Books, NewYork.

Wedel, W.L. 1961. Prehistoric Man on the Great Plains. University of Oklahoma Press, Norman.

Weiner, M.A. 1972. Earth Medicine - Earth Foods. The Macmillan Company, New York.

* Appendix is available upon request. Contact UW-NPS through our website www.uwyo.edu/uwnps 
Wright, G., A. 1984. People of the High Country. Peter Lang Publishing Inc., New York.

Wyoming State Preservation Office. 2005. Office of Cultural Records, Mary Hopkins, Manager, Laramie, Wyoming. 